\title{
Överbehandling av patienter med demens
}

\author{
Trots att målsättningen är palliativ \\ sker en omfattande medicinsk \\ behandling i livets slutskede av \\ patienter med demens.
}

I en nyligen publicerad amerikansk studie undersöktes 323 patienter med avancerad demenssjukdom (1). Det var en multicenterstudie med patienter som vårdades på sjukhem. Patienterna följdes upp under 18 månader. Under denna period avled $54 \%$. Pneumoni, feberepisoder och svårigheter med att äta var mycket vanligt under studietiden. Om någon av dessa tre komplikationer tillstötte, försämrades prognosen markant.

Under de sista tre månaderna i livet behandlades $41 \%$ av patienterna som avled under studieperioden med en medicinsk intervention. Parenteral terapi gavs till $34 \%, 17 \%$ blev hospitaliserade, $10 \%$ skickades till akutmottagningen och $8 \%$ fick enteral sond. De närstående familjemedlemmarna intervjuades, och av dessa rapporterade $96 \%$ att palliation var primära målet för vården. Bara $18 \%$ av dessa familjemedlemmar hade fătt information av läkare om prognosen.

Författarna konkluderar att mortaliteten vid allvarlig demenssjukdom är mycket hög. Trots att behandlingen definierades som palliativ, så var medicinska interventioner mycket vanliga bland de patienter som sen avled. «Risken» för medicinsk intervention var betydligt lägre för de patienter som hade anhöriga som hade kunskap om prognosen och som förstod att medicinska komplikationer sannolikt skulle uppstå.
Denna studie utfördes i östra USA. Utan att ha exakta data är det min känsla att detta också sker på samma sätt i de skandinaviska länderna. Är det etiskt att behandla en patient med uttalad demens med akut sjukhusvård?

\section{Stefan Agewall}

stefan.agewall@medisin.uio.no

Medisinsk klinikk

Oslo universitetsykehus, Aker

\section{Litteratur}

1. Mitchell SL, Teno JM, Kiely DK et al. The clinical course of advanced dementia. N Engl J Med 2009. 361: 1529-38.

\section{Røykeavvenning og lungekreft}

Røykeslutt før diagnosen innebærer at av alle de histologiske hovedtypene er risikoen for å utvikle primært lungekarsinom redusert. Engelske forskere har nå undersøkt om røykestopp etter lungekreftdiagnosen gir økt overlevelse (BMJ 2010; 340: b5569).

Ingen randomiserte studier ble funnet, men longitudinelle observasjonsstudier ble inkludert i metaanalysen. De fleste pasientene i studien fikk diagnosen i et tidlig stadium. Fortsatt røyking var forbundet med $\varnothing k t$ risiko for $\mathrm{d} ø \mathrm{~d}$ av alle årsaker, for residiv og for utvikling av annen primærsvulst. Fordelene med å slutte å røyke synes i hovedsak å være redusert kreftutvikling. snarere enn mindre risiko for kardiorespiratorisk død. Resultatene antyder at røykeavvenning kan være gunstig for pasienter i tidlig stadium av lungekreft.

\section{Hypogonadisme og alder}

Reduksjon i testosteronnivåene med $ø$ kende alder hos menn kan føre til liknende symptomer som ved hypogonadisme. Nå har italienske forskere sett på sammenhengen mellom slike symptomer og alder hos 1647 menn med seksuell dysfunksjon (Int J Androl 2009; 32: 720-8).

I alle alderskvartiler var lavt testosteronnivå assosiert med større livvidde, høyere triglyseridnivåer og økt prevalens av metabolsk syndrom. Studien viste at for dem med seksuell dysfunksjon kan enkelte hypogonadismerelaterte symptomer være aldersspesifikke. Lave testosteronverdier var oftere assosiert med seksuell dysfunksjon hos de eldste mennene.

\section{Matsopp virker immunmodulerende}

\section{Soppen Agaricus blazei Murill kan motvirke kreft, sepsis og allergi i mus. Nå prøves den ut ved inflam- matorisk tarmsykdom og myeloma- tose.}

Soppen brukes i folkemedisinen mot bl.a. kreft. Nylig ble det vist at den har sterke immunmodulerende effekter, øker overlevelsen ved sepsis og hemmer myelomer og annen kreft i mus (1). I musestudier reduserte soppen også Th2-responsen i forhold til Th1-responsen og motvirket allergi (2). Dette forklares med at antitumor- og antiinfeksjons-T-hjelpecelle 1responser er inverst relatert til proallergisk Th2-respons. I humanstudier er det vist at soppen øker NK-celleaktiviteten og reduserer bivirkningene av høydosekjemoterapi ved gynekologisk kreft og oppregulerer gener som hemmer celledeling og gir apoptose (1).

I en ny studie har vi vist at friske frivillige ikke hadde bivirkninger eller negative effekter og fikk reduserte nivåer av proinflammatoriske cytokiner som TNF- $\alpha$ og IL-8 (3). Ved Oslo universitetssykehus, Ullevål, gjennomføres det nå studier med pasienter med inflammatorisk tarmsykdom og myelomatose. I tillegg til annen behandling får de ekstrakt av Agaricus blazei Murill.

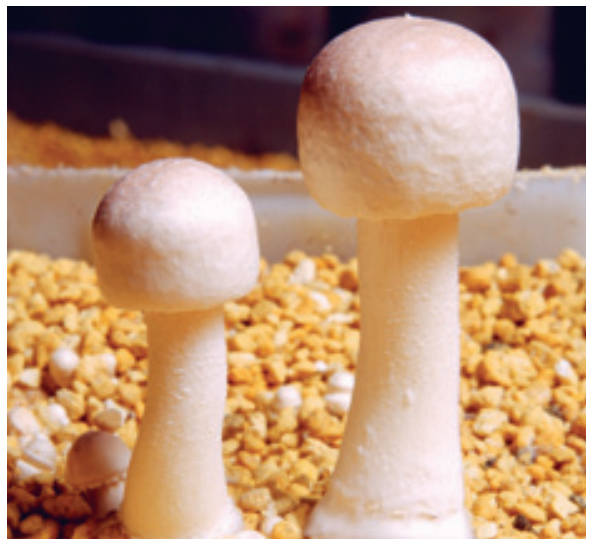

Agaricus blazei Murill. Foto @ NutriCon

\section{Geir Hetland}

geir.hetland@rikshospitalet.no

Oslo universitetssykehus, Rikshospitalet

\section{Egil Johnson}

Oslo universitetssykehus, Ullevål

\section{Litteratur}

1. Hetland G, Johnson E, Lyberg T et al. Effects of the medicinal mushroom Agaricus blazei Murill on immunity, infection and cancer. Scand J Immunol 2008; 68: 363-70.

2. Ellertsen LK, Hetland G. An extract of the medicinal mushroom Agaricus blazei Murill can protect against allergy. Clin Mol Allergy 2009; 7: 6.

3. Johnson E, Førland DT, Saetre L et al. Effect of an extract based on the medicinal mushroom Agaricus blazei murill on release of cytokines, chemokines and leukocyte growth factors in human blood ex vivo and in vivo. Scand J Immunol 2009; 69: $242-50$. 